\title{
Potential for spatial displacement of Cook Inlet beluga whales by anthropogenic noise in critical habitat
}

\author{
Robert J. Small ${ }^{1, *}$, Brian Brost ${ }^{2}$, Mevin Hooten ${ }^{3,2,4}$, Manuel Castellote ${ }^{5,6}$, \\ Jeffrey Mondragon ${ }^{1}$
}

\author{
${ }^{1}$ Alaska Department of Fish and Game, 1255 West 8th Street, Juneau, AK 99801, USA \\ ${ }^{2}$ Department of Fish, Wildlife, and Conservation Biology, Colorado State University, 1484 Campus Delivery, Fort Collins, \\ CO 80523, USA \\ ${ }^{3}$ U.S. Geological Survey, Colorado Cooperative Fish and Wildlife Research Unit, 1484 Campus Delivery, Fort Collins, \\ CO 80523, USA \\ ${ }^{4}$ Department of Statistics, Colorado State University, 1484 Campus Delivery, Fort Collins, CO 80523, USA \\ ${ }^{5}$ Joint Institute for the Study of the Atmosphere and Ocean (JISAO), University of Washington, 3737 Brooklyn Avenue NE, \\ Seattle, WA 98105, USA \\ ${ }^{6}$ Alaska Fisheries Science Center, Marine Mammal Laboratory, 7600 Sand Point Way NE, Seattle, WA 98115, USA
}

\begin{abstract}
The population of beluga whales in Cook Inlet, Alaska, USA, declined by nearly half in the mid-1990s, primarily from an unsustainable harvest, and was listed as endangered in 2008. In 2014 , abundance was $\sim 340$ whales, and the population trend during 1999-2014 was $-1.3 \% \mathrm{yr}^{-1}$. Cook Inlet beluga whales are particularly vulnerable to anthropogenic impacts, and noise that has the potential to reduce communication and echolocation range considerably has been documented in critical habitat; thus, noise was ranked as a high potential threat in the Cook Inlet beluga Recovery Plan. The current recovery strategy includes research on effects of threats potentially limiting recovery, and thus we examined the potential impact of anthropogenic noise in critical habitat, specifically, spatial displacement. Using a subset of data on anthropogenic noise and beluga detections from a 5 yr acoustic study, we evaluated the influence of noise events on beluga occupancy probability. We used occupancy models, which account for factors that affect detection probability when estimating occupancy, the first application of these models to examine the potential impacts of anthropogenic noise on marine mammal behavior. Results were inconclusive, primarily because beluga detections were relatively infrequent. Even though noise metrics (sound pressure level and noise duration) appeared in high-ranking models as covariates for occupancy probability, the data were insufficient to indicate better predictive ability beyond those models that only included environmental covariates. Future studies that implement protocols designed specifically for beluga occupancy will be most effective for accurately estimating the effect of noise on beluga displacement.
\end{abstract}

KEY WORDS: Beluga whales · Anthropogenic noise $\cdot$ Spatial displacement · Occupancy models

\section{INTRODUCTION}

Beluga whales Delphinapterus leucas in Cook Inlet, Alaska, USA, are a genetically distinct and geographically isolated population that remains year-round in the inlet (O'Corry-Crowe et al. 1997, Laidre et al. 2000, Rugh et al. 2000). Counts from aerial surveys indicate that the abundance of this population declined

*Corresponding author: bob.small@alaska.gov by nearly half, from 653 to 347 whales in the 4 yr between 1994 and 1998. The rapid decline was attributed to a substantial and unregulated subsistence hunt, and although subsistence hunts have been regulated since 1999, Cook Inlet belugas were designated as depleted in 2000 and listed as endangered in 2008. In $2011,7800 \mathrm{~km}^{2}$ of marine waters were designated as critical habitat, composed of 2 areas: Area 1, 1909

() The authors and (outside the USA) the US Government 2017. Open Access under Creative Commons by Attribution Licence. Use, distribution and reproduction are unrestricted. Authors and original publication must be credited.

Publisher: Inter-Research · www.int-res.com 
$\mathrm{km}^{2}$ of northern Cook Inlet; and Area 2, $5891 \mathrm{~km}^{2}$ of the mid-inlet and coastal areas extending to the southern limit of the inlet (Fig. 1) (76 FR 20180; 50 CFR part 226.220, Recovery Plan; NMFS 2016). Area 1 has the highest concentration of belugas during the ice-free period, when the whales are known to forage extensively, and also has the greatest potential for adverse impact from anthropogenic threats. The most recent abundance estimate, in 2014, was 340 whales (CV 0.08), and the population trend over the $15 \mathrm{yr}$ period between 1999 and 2014 was $-1.3 \%$ annually (SE $0.7 \%$ ) (Shelden et al. 2015), indicating these whales may become extinct unless factors that are impeding recovery are determined and mitigated (Hobbs et al. 2008, NMFS 2016).

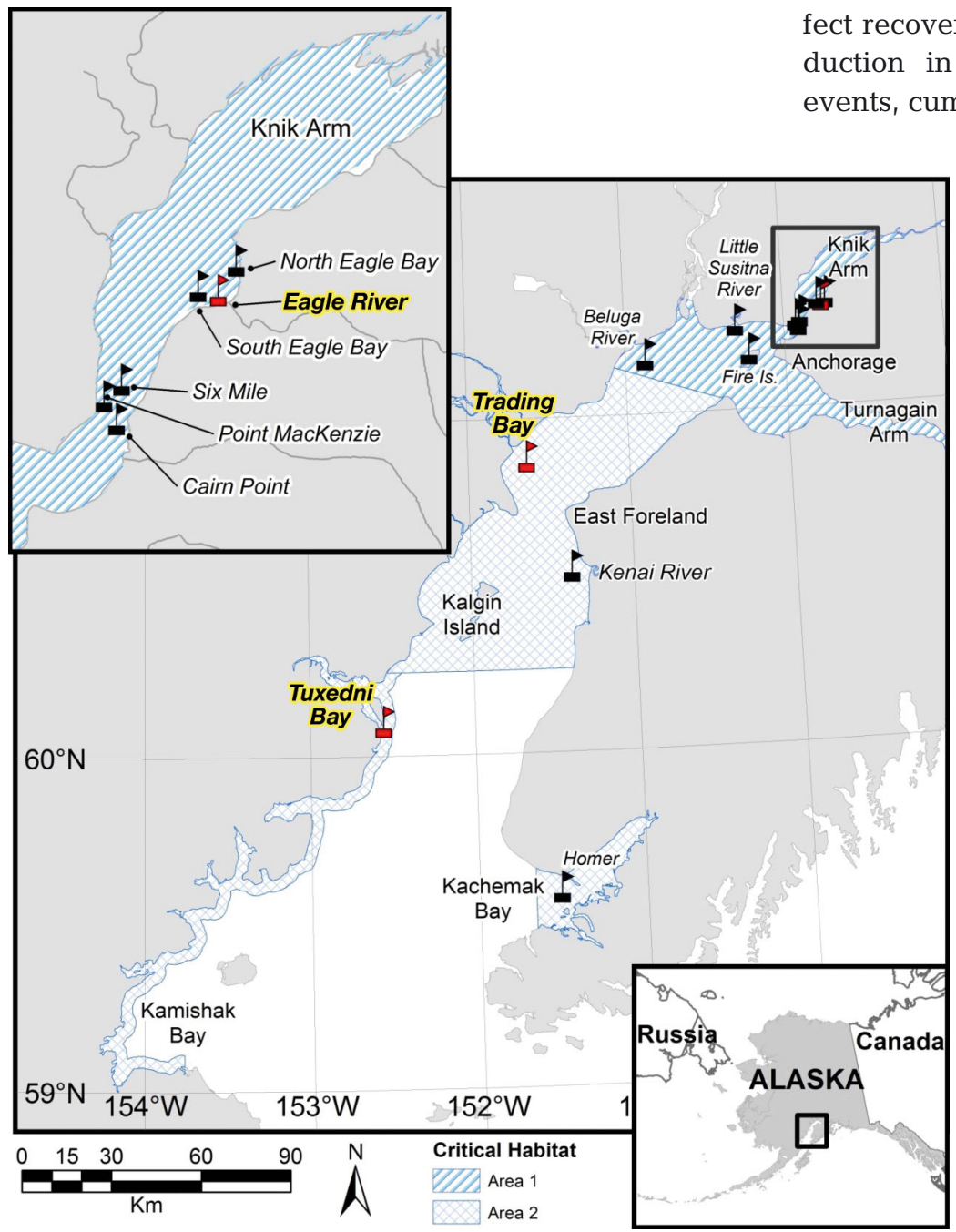

Fig. 1. Location of acoustic moorings in beluga whale critical habitat where anthropogenic noise and beluga whale detections were monitored in Cook Inlet, Alaska, USA, 2008-2013. Only data obtained at the 3 locations highlighted in yellow (Eagle River, Trading Bay, and Tuxedni Bay) were used to evaluate potential spatial displacement of beluga whales by anthropogenic noise
Cook Inlet beluga whales are particularly vulnerable to anthropogenic impacts due to their small population size, geographic and genetic isolation, strong site fidelity, and the close proximity of critical habitat to Alaska's largest urban area, which exposes belugas to a wide variety of stressors. With relatively scant information about this population of belugas and uncertainty about which threats may be impeding recovery, the Recovery Plan (NMFS 2016) identified 10 potential threats and their respective relative concern as either having a 'High', 'Medium', or 'Low' potential for affecting the population's ability to recover. Further, the recovery strategy includes conducting research on the possible effects of these threats and integrating the results into conservation actions (NMFS 2016). The 3 threats identified as having high potential to affect recovery (ranked above habitat loss, disease, reduction in prey, and predation) are catastrophic ative and synergistic effects, and noise. Based on this ranking of threats, our study examines the potential impact of anthropogenic noise on beluga whales in their critical habitat of Cook Inlet.

An extensive body of literature looks at the effects of anthropogenic noise on marine mammals. Most studies have examined the possible disturbance and stress caused by noise through changes in behavioral attributes, such as temporary spatial displacements, or changes in site fidelity, dive patterns, swimming speed, travel orientation, herd cohesiveness, and dive synchrony (see Nowacek et al. 2007 for a review). The consequences of such changes in behavior are not yet well understood, despite considerable research designed to determine their biologically significant effects (e.g. NRC 2005, Tyack et al. 2011, Noren et al. 2012, New et al. 2013, Harwood et al. 2016). However, there is sufficient evidence to suggest that cumulative and chronic effects of disturbance can negatively impact cetacean reproductive success and survival (Tyack \& Clark 2000, Cox et al. 2006, Southall et al. 2007, Clark et al. 2009, Dekeling et al. 2014, Wright \& Kyhn 2015, Fleishman et al. 2016).

Beluga whales are vulnerable to impacts from noise due to their high auditory sensitivity, wide hearing frequency range, and their dependence on sound 
to navigate, communicate, locate and capture prey, and find breathing holes in ice. Studies examining the influence of anthropogenic noise on belugas have identified several potential impacts: threshold shifts in beluga hearing capabilities (Finneran et al. 2000, 2002, Schlundt et al. 2000); masking of the ability of animals to hear and decipher specific sounds (Erbe et al. 1999, Erbe 2000); altered vocal behaviors (Lesage et al. 1999, Scheifele et al. 2005); and, spatial displacement of animals from their habitats (Finley et al. 1990, Richardson et al. 1995).

Temporary spatial displacement of cetaceans can occur at great distances from the noise source, which is typically interpreted as an early behavioral response to disturbance caused by noise exposure, e.g. narwhals at $>200 \mathrm{~km}$ (Heide-Jørgensen et al. 2013) and fin whales at $285 \mathrm{~km}$ (Castellote et al. 2012). Spatial displacements of belugas by loud noise sources have been documented. Specifically, belugas typically avoided icebreakers at distances of $35-50 \mathrm{~km}$, the distance at which they could probably detect noise generated by the vessel (Finley et al. 1990, Cosens \& Dueck 1993). Furthermore, the 2000-2001 marine mammal monitoring and mitigation program conducted in the MacKenzie Delta in the Canadian Beaufort Sea determined that belugas reacted to seismic operations at distances $>20 \mathrm{~km}$ (Miller et al. 2005). Similarly, in 2007-2008 another seismic and exploratory drilling activity was conducted in the same area and at the same time of year, and aerial surveys determined that belugas were rarely sighted from seismic ships but were widely distributed offshore during the operation period. These results suggest that belugas tended to temporarily avoid areas of seismic activity at distances greater than the range covered by marine mammal observers onboard seismic vessels (Harwood et al. 2010).

Spatial displacement and changes in beluga behavior are apparently greater in response to a moving sound source (e.g. air gun activity on a moving vessel) than to a stationary sound source. For example, when drilling sounds were played from a small vessel in areas without industrial activity, belugas exhibited displacement only when received levels were high (Richardson \& Würsig 1997). Similarly, startle responses by belugas were observed when drilling noises with a received level $\geq 153 \mathrm{~dB}_{\text {rms }}(\mathrm{dB}$ root mean square) re $1 \mu \mathrm{Pa}$ were played from a moving platform. In contrast, Richardson et al. (1995) reported that in ensonified zones near industrial sites with stationary platforms, including dredges, belugas were present, and changes in behavior were not documented in response to disturbance from the industrial activities.
Even though the relative concern for noise affecting the recovery of Cook Inlet beluga whales was ranked as High in the Recovery Plan, the possible effects of disturbance from anthropogenic noise on this endangered species have not yet been examined. As such, the primary recovery action is to assess (including through retrospective analyses) if noise is limiting Cook Inlet beluga recovery through behavioral responses, such as spatial displacement from important habitats. The first component of such an assessment is to describe and characterize the acoustic diversity and occurrence of anthropogenic noise sources in the context of their effects on Cook Inlet beluga hearing and communication. Castellote et al. (2016a) conducted such an analysis, based on acoustic data obtained from a $5 \mathrm{yr}$ research program designed to detect belugas in Cook Inlet, for which documenting anthropogenic noise sources was a secondary objective. We have included a brief summary of that analysis in our 'Results' section.

The objective of our study is to address the second component of the recovery action: evaluate the influence of anthropogenic noise events (and habitat conditions, e.g. water level) on beluga habitat use. Whereas detection of beluga whales indicates their presence, lack of detection does not necessarily indicate their absence. Differences in environmental conditions, background noise levels, or beluga whale behavior may all influence acoustic detectability of whales. If ignored, imperfect detection leads to underestimation of true occurrence, as well as biased relationships between occurrence and habitat features or environmental conditions (MacKenzie et al. 2002, 2006). Factors affecting detection may further be incorrectly identified as determinants of occurrence. Occupancy models represent the only framework available that is unaffected by these issues when detection is imperfect (MacKenzie et al. 2002, 2006). In this study, we used occupancy models to investigate the effect of anthropogenic noise events and habitat conditions (e.g. water level) on Cook Inlet beluga whale occurrence. To our knowledge, this is the first application of occupancy models to examine the potential impacts of anthropogenic noise on marine mammal behavior.

\section{MATERIALS AND METHODS}

\section{Beluga detection data}

As described in Lammers et al. (2013) and Castellote et al. (2016b), during July 2008 to May 2013 
acoustic data were collected from 13 moorings deployed in Cook Inlet beluga critical habitat (Fig. 1), with the primary objective of detecting belugas (and other odontocetes) and documenting anthropogenic noise as a secondary objective. Two types of acoustic sensors were used: an ecological acoustic recorder (EAR) and a cetacean and porpoise detector (CPOD). The EAR is a computer-based recorder with a programmable duty cycle and bandwidth (up to $40 \mathrm{kHz}$ ), which we programmed at a sample rate of $25 \mathrm{kHz}$ (providing a recording bandwidth of 0-12 $\mathrm{kHz}$ ) to record beluga social signals, e.g. calls, whistles, and buzzes. The C-POD is an echolocation logger that detects and classifies higher frequency echolocation signals from odontocetes; we set up the C-POD to scan continuously in a $20-160 \mathrm{kHz}$ frequency range to log and classify echolocation clicks from belugas.

Beluga vocalizations span a broad range of frequencies. Social sounds, including calls, whistles, and buzzes generally occur at frequencies below $\sim 12 \mathrm{kHz}$, although many signals are broadband and have energy above $20 \mathrm{kHz}$ (Sjare \& Smith 1986, Ford 1989, Thomsen et al. 2001, Chmelnitsky \& Ferguson 2012). Echolocation clicks are emitted at higher frequencies than social sounds, with peak frequencies between 40 and $120 \mathrm{kHz}$ (Au et al. 1985). Source levels for these signals can be as high as $212 \mathrm{~dB}$ peak to peak $\left(\mathrm{dB}_{\mathrm{p}-\mathrm{p}}\right)$ re $1 \mu \mathrm{Pa}$ at $1 \mathrm{~m}$ (Au et al. 1987); therefore, these signals are loud and easy to identify, and will most likely be detected when belugas vocalize within the recorder's range. Detection range for Cook Inlet belugas has been estimated to be $\sim 2$ to $3 \mathrm{~km}$ for social signals and $900 \mathrm{~m}$ for echolocation (Lammers et al. 2013, Castellote et al. 2016a). Obviously, belugas that do not vocalize within the recorder's range will not be detected, and although periods without social signals are possible, the absence of any echolocation by belugas in Cook Inlet is likely very rare because of the need to navigate in the extremely turbid waters (Castellote et al. 2016a).

EARs were set to record on a $10 \%$ duty cycle, being on for $30 \mathrm{~s}$ followed by $270 \mathrm{~s}$ of inactivity, during 2 deployment periods of $\sim 22-24$ wk each year. Beluga detections from EARs were summarized by 'encounters' (Lammers et al. 2013), which represent the period of time from an initial detection through all subsequent detections that occur within $60 \mathrm{~min}$ of each other. Thus, all detections within an encounter may be separated by up to $59 \mathrm{~min}$; gaps of $60 \mathrm{~min}$ or more between detections separate discrete encounters. Beluga detections from EARs were based on a $1 \mathrm{~h}$ temporal resolution. Beluga detections from
C-PODs were based on a 1 min temporal resolution and were not summarized into encounters in a manner similar to the EAR detection data. Prior to analysis, we aggregated the 1 min detection data from the $\mathrm{C}$-PODs to match the $1 \mathrm{~h}$ resolution of the EAR data.

\section{Anthropogenic noise and water level data}

As described by Castellote et al. (2016a), a subset of the EAR recordings was selected to be analyzed for sources and characteristics of anthropogenic noise; funding and time constraints did not allow the full dataset to be analyzed. The selection was based on (1) the amount and diversity of anthropogenic noise found in the recordings when the data was analyzed for odontocete signal detections, and (2) the diversity and spatial and temporal occurrence of anthropogenic noise occurring in Cook Inlet beluga critical habitat. The subset included recordings obtained at 7 of the 13 moorings during the months of February, March, April, May, August, September, and December, 2009-2012 (Table 1). The subset had $8756 \mathrm{~h}$ of recordings ( $11.7 \%$ of the total available), from which 6263 anthropogenic acoustic events were analyzed; these had a total duration of $1025 \mathrm{~h}$ and were classified into 13 anthropogenic noise classes. The initial and final time and date of all noise events were used to describe the temporal presence of anthropogenic noise in the selected data for this study. Multiple acoustic parameters were measured for each noise event. For our study, we specifically examined 2 of those parameters: sound pressure level (SPL in $\mathrm{dB}_{\text {rms }}$ re $1 \mu \mathrm{Pa}$ ) and noise duration (measured as the difference between the start and end times of the event, including recording stand-by periods when events spanned over multiple consecutive files), because they summarize the most important acoustic features in both the energy and temporal domains. Importantly, as noted by Castellote et al. (2016a), the acoustic study was designed primarily for the long-term detection of beluga whale signals, not recordings of anthropogenic noise. Thus, there are 3 important limitations to the noise data: (1) to reduce power consumption by the $\mathrm{EAR}$, the sampling rate was set to $0-12.5 \mathrm{kHz}$, and although most anthropogenic noises have acoustic energy below $12.5 \mathrm{kHz}$, some were above this level, but these were not recorded; (2) the duty cycle $(10 \%)$ restricted sound files to $30 \mathrm{~s}$ duration, and thus noise events $>30 \mathrm{~s}$ (or cut by the beginning or ending of the sound file) were truncated, which resulted in durations and all pressure-related measurements (i.e. SPL, sound 
Table 1. Beluga detection data and anthropogenic noise events obtained by ecological acoustic recorders (EARs) and cetacean and porpoise detectors (C-PODs) at mooring sites in Cook Inlet, Alaska, USA. Only the 3 locations in bold (Eagle River, Trading Bay, and Tuxedni Bay) provided data suitable to evaluate potential spatial displacement by anthropogenic noise

\begin{tabular}{|c|c|c|c|c|c|c|c|c|c|c|}
\hline \multirow{2}{*}{$\begin{array}{l}\text { Mooring } \\
\text { location }\end{array}$} & \multicolumn{2}{|c|}{ — Period sampled } & \multicolumn{3}{|c|}{ EAR $1 \mathrm{~h}$ samples } & \multicolumn{3}{|c|}{ C-POD $1 \mathrm{~h}$ samples } & \multicolumn{2}{|c|}{ Anthropogenic noise } \\
\hline & (dd.mm.yy) & $\begin{array}{c}\text { No. of } \\
\text { days }\end{array}$ & $\begin{array}{l}\text { No. of } \\
\text { beluga } \\
\text { detections }\end{array}$ & $\begin{array}{c}\text { No. of } \\
\text { samples }\end{array}$ & $\begin{array}{l}\% \text { of samp- } \\
\text { les with } \\
\text { detection }\end{array}$ & $\begin{array}{c}\text { No. of } \\
\text { beluga } \\
\text { detections }\end{array}$ & $\begin{array}{c}\text { No. of } \\
\text { samples }\end{array}$ & $\begin{array}{l}\% \text { of samp- } \\
\text { les with } \\
\text { detection }\end{array}$ & $\begin{array}{l}\text { No. of } \\
\text { events }\end{array}$ & $\begin{array}{c}\text { No. of } \\
\text { events } d^{-1}\end{array}$ \\
\hline Eagle River & 01.08.10-28.09.10 & 58.5 & 236 & 1405 & 16.8 & 438 & 1405 & 31.2 & 104 & 1.8 \\
\hline Six Mile & $02.12 .11-31.12 .11$ & 29.4 & 16 & 706 & 2.3 & - & - & - & 245 & 8.2 \\
\hline Six Mile & 01.05.12-21.05.12 & 21.3 & 2 & 511 & 0.4 & - & - & - & - & - \\
\hline Cairn Point & $01.08 .10-31.08 .10$ & 31.0 & 8 & 744 & 1.1 & 0 & 744 & 0.0 & 4757 & 153.5 \\
\hline Cairn Point & 01.04.11-03.04.11 & 2.6 & 3 & 63 & 4.8 & - & - & - & 58 & 19.3 \\
\hline Fire Island & 01.08.09-24.08.09 & 23.5 & 1 & 564 & 0.2 & - & - & - & 200 & 8.3 \\
\hline Fire Island & $25.08 .09-28.09 .09$ & 34.2 & 14 & 821 & 1.7 & 1 & 29 & 3.4 & 257 & 7.3 \\
\hline Fire Island & 01.12.09-31.12.09 & 31.0 & 11 & 744 & 1.5 & - & - & - & - & - \\
\hline Trading Bay ${ }^{\mathrm{a}}$ & $01.02 .12-22.04 .12$ & 81.3 & 154 & 1951 & 7.9 & $\mathbf{0}$ & 1229 & 0.0 & 529 & 6.5 \\
\hline Kenai River & $01.04 .12-22.04 .12$ & 21.4 & 10 & 513 & 1.9 & 2 & 513 & 0.4 & 85 & 3.9 \\
\hline Tuxedni Bay & 01.03.12-31.03.12 & 31.0 & 85 & 744 & 11.4 & 21 & 744 & 2.8 & 28 & 0.9 \\
\hline
\end{tabular}

exposure level [SEL], peak pressure) being inherently conservative; and (3) the recording gain on the EARs was set to enhance the detection of faint, faraway beluga vocalizations, and signals louder than $153 \mathrm{~dB}$ (peak to peak) exceeded the upper limit for accurately recorded signals and were clipped (i.e. the upper and lower limits of the waveform are cut), which resulted in biased measurements and decreased accuracy in the assessment of signals with the highest $d B$ levels. Clipping occurred in a very small proportion of the selected data for this analysis, less than $1 \%$ in Eagle River and Trading Bay, and none in Tuxedni Bay.

Data on water levels in Cook Inlet were obtained from the National Oceanic and Atmospheric Administration's tides and currents program (www.tidesand currents.noaa.gov). Measured water levels were available for Anchorage (station ID: 9455920) at 6 min intervals and were averaged to obtain hourly water levels for the Eagle River mooring site; the distance between the tide station and mooring was $\sim 12.9 \mathrm{~km}$. Measured water level data were unavailable for stations near Tuxedni Bay, and so we interpolated linearly the high/low tide predictions from Tuxedni Channel (station ID: 9456204; $7.4 \mathrm{~km}$ from our mooring) to obtain hourly water level estimates for the Tuxedni Bay mooring site. Measured water levels at 6 min intervals were partially available for Nikiski (station ID: 9455760; $25.9 \mathrm{~km}$ from our mooring); however, several gaps were present in this data set. To fill the data gaps, we interpolated water level measurements from high/low tide predictions for the Trading Bay mooring site. Analysis of beluga occupancy was limited to data collected at the mooring sites with the greatest proportion of beluga detections: Eagle River, Trading Bay, and Tuxedni Bay mooring sites (see 'Beluga detections and anthropogenic noise events'); therefore, water level data were not obtained for the remaining mooring sites (Six Mile, Cairn Point, Fire Island, and Kenai River). All water level data were measured relative to the mean lower-low water (MLLW) datum.

\section{Modeling beluga occupancy}

We used occupancy models (MacKenzie et al. $2002,2006)$ to quantify the effect of anthropogenic noise and environmental conditions on beluga occupancy at acoustic mooring sites. Occupancy models are powerful analytical tools because they can be used to provide inference for the true occupancy probability $(\psi)$ while accounting for imperfect and varying detection probabilities (p). Occupancy models consist of a mixture of 2 coupled sub-models, one for the observation (detection) process and another for the biological (occupancy) process of interest.

Traditionally, occupancy models were developed to account for imperfect detection while estimating occupancy status (and environmental drivers of occupancy) in a set of sites that have been surveyed multiple times in a study period. In this context, for statistical inference on detection and occupancy directly, the occupancy model assumes binomial sampling (i.e. only false negatives, not false positives), closure at the site level during the study period (i.e. no immi- 
gration or emigration during the study period), and conditional independence among repeated surveys at a site (i.e. observed occupancy status given detection probability for one survey during the study period does not depend on that of other surveys). When these assumptions are valid, the occupancy model allows one to statistically separate detection and occupancy inference using replicate surveys at each site.

We can translate the site occupancy model to the temporal domain if we treat sites as subperiods of time within a larger study period. The repeated visits (or multiple surveys) must occur within each subperiod. For example, we selected subperiods consisting of continuous $3 \mathrm{~h}$ intervals to serve as the sites, with $1 \mathrm{~h}$ 'replicates' within each subperiod as surveys. Consequently, each subperiod consisted of 6 sampling occasions: 3 opportunities to detect beluga whales from the EARs and 3 opportunities to detect beluga whales from the C-PODs. We selected a $3 \mathrm{~h}$ subperiod because it allows for better estimation of detection probability than a shorter $2 \mathrm{~h}$ subperiod (the shortest sampling period that achieves repetition given the $1 \mathrm{~h}$ resolution of the EAR detection data), while also being relatively homogenous with respect to dynamic environmental conditions (such as water levels). The analyzed sites were separated by $\sim 100 \mathrm{~km}$ each, thus eliminating the potential that beluga whales could be detected at 2 or more sites during the same subperiod.

In this setting, the temporal occupancy model will partition the temporally varying beluga detections into a large-scale temporal trend and a smaller scale thinning process. If the closure assumption is valid, then the large-scale trend represents beluga occu- pancy status changing over time, and the thinning process represents changes in detectability over time (assuming no false positives). If the closure assumption is not met in the temporal occupancy model, then we are limited to using the model phenomenologically to predict beluga detections, and the 2 processes cannot necessarily be interpreted as occupancy and detection. Nonetheless, we can still fit the temporal occupancy model to the data and compare models based on a variety of predictors in both the temporal trend and thinning process, in terms of predictive ability using Akaike's information criterion (AIC).

We fit numerous temporal occupancy models using a variety of environmental and noise predictors, in both the trend and thinning processes. Estimation of the trend process is subject to bias if species detection probability is <1 (MacKenzie et al. 2002); consequently, we first evaluated factors affecting the thinning process at the $1 \mathrm{~h}$ temporal resolution. We developed 11 a priori models to assess the influence of SPL, duration of noise event, mooring site, and device (EAR vs. C-POD) on thinning (Table 2). Given expectations that the thinning process varies with site (e.g. variability in acoustic propagation conditions) and device (e.g. detection range), all models included one or both covariates. Because SPL and noise duration were highly correlated $(r=0.96)$, we did not include both covariates in the same model. We expected the trend process to vary by mooring site and water level; therefore, these models contained the additive or interactive effects of both covariates in the trend (i.e. occupancy) sub-model. We also included a quadratic effect of water level in some models (Table 2). We subsequently used the

Table 2. Model selection results for the 11 a priori models used to examine the effects of sound pressure level (SPL), duration of anthropogenic noise event (duration), mooring site (site), and device (ecological acoustic recorders vs. cetacean and porpoise detectors) on beluga detection probability (p). Occupancy probability was modeled as a function of water level and mooring site; + : additive effect, $\times$ : interaction. Column headings denote $-\log$ likelihood $(-\log (L))$, the number of model parameters $(K)$, Akaike's information criterion (AIC) values, and differences in AIC values compared to the top model ( $\triangle$ AIC). The model receiving the most empirical support is in bold

\begin{tabular}{|c|c|c|c|c|c|}
\hline Detection model & Occupancy model & $-\log (L)$ & $K$ & AIC & $\Delta \mathrm{AIC}$ \\
\hline Site + Device & Water level + Site & 1838.94 & 8 & 3693.88 & 12.43 \\
\hline Site + Device + SPL & Water level + Site & 1838.69 & 9 & 3695.39 & 13.94 \\
\hline Site + Device + Duration & Water level + Site & 1838.92 & 9 & 3695.85 & 14.4 \\
\hline Site + Device & Water level $\times$ Site & 1830.73 & 10 & 3681.45 & $\mathbf{0}$ \\
\hline Site + Device + SPL & Water level $\times$ Site & 1830.54 & 11 & 3683.07 & 1.62 \\
\hline Site + Device + Duration & Water level $\times$ Site & 1830.69 & 11 & 3683.37 & 1.92 \\
\hline Site + Device & Water level $\times$ Site + Water level ${ }^{2}$ & 1830.06 & 11 & 3682.12 & 0.67 \\
\hline Site + Device + SPL & Water level $\times$ Site + Water level $^{2}$ & 1829.86 & 12 & 3683.72 & 2.27 \\
\hline Site + Device + Duration & Water level $\times$ Site + Water level $^{2}$ & 1830.03 & 12 & 3684.05 & 2.6 \\
\hline Site & Water level $\times$ Site & 1884.51 & 9 & 3787.03 & 105.58 \\
\hline Device & Water level $\times$ Site & 1862.21 & 8 & 3740.41 & 58.96 \\
\hline
\end{tabular}


best model structure for the thinning process (i.e. model with the lowest $\mathrm{AIC}$; see below) when refining the model structure for the trend process.

We considered 15 a priori models for the trend process of beluga whales (Table 3). Given our expectation that water level and mooring site influence trends in beluga detections, all but one model contained the additive or interactive effects of both variables. Candidate models were proposed with increasing complexity with respect to anthropogenic noise metrics, but highly correlated variables were not included in the same model (SPL and noise duration). We used a subset of the models to explore the influence of a quadratic effect of water level on the trend process. We also fit a constant, intercept-only model as a benchmark for comparing more complex models. Because the trend process is evaluated at the scale of $3 \mathrm{~h}$ subperiods, covariates in these models represented the average value across subperiods.

We fit all models using the 'occu' function in the unmarked package (Fiske \& Chandler 2011) for R (R Core Team 2014) and used AIC to compare candidate models for the beluga detection thinning and trend processes (Burnham \& Anderson 2002). The model with the smallest AIC value is considered to have the best predictive ability based on in-sample empirical data, whereas models with AIC values $>10$ units larger than the best predictive model (i.e. $\triangle \mathrm{AIC}$
$>$ 10) have substantially worse predictive ability by comparison (Burnham \& Anderson 2002). However, care must be taken when interpreting models with $\Delta$ AIC $<2$. Models having $\triangle$ AIC $<2$ may not actually be better for prediction if they differ by 1 parameter from the best model. In this case, the more complex model is not competitive because the penalty for an additional parameter is not offset by a decrease in model deviance (Burnham \& Anderson 2002, Arnold 2010). In other words, the additional parameter may not be aiding predictive ability. A similar caveat also applies to models that have 2 additional parameters and $\triangle$ AIC $<4$. Model selection criteria like AIC are useful for selecting the 'best' model from a set of candidate models, but they do not guarantee the selection of a 'good' model unless one or more of the candidates fit the data adequately. Therefore, we also examined goodness-of-fit using the Pearson chi-square statistic and a parametric bootstrap procedure to test the null hypothesis that model fit is adequate (MacKenzie \& Bailey 2004). We used 1000 bootstrap samples to test goodness-of-fit, where the proportion of chi-square statistics obtained from the bootstrap samples that are greater than the statistic obtained from the observed beluga data is the $\mathrm{p}$-value associated with the test. Prior to model fitting, all continuous covariates were centered and scaled to unit variance.
Table 3. Model selection results for the 15 a priori models used to examine the effects of water level, mooring site (site), sound pressure level (SPL), duration of anthropogenic noise event (duration), and time since last noise event ended (time) on beluga occupancy probability $(\psi)$. Models of occupancy probability consisted of both additive $(+)$ and interactive $(\times)$ effects. Column headings denote $-\log$ likelihood $(-\log (L))$, the number of model parameters $(K)$, Akaike's information criterion (AIC) values, and differences in AIC values compared to the top model $(\triangle \mathrm{AIC})$. The model receiving the most empirical support is in bold. -: intercept-only model. Detection probability was modeled as a function of mooring site and device in all models

\begin{tabular}{|lcccc|}
\hline Occupancy model & $-\log (L)$ & $K$ & AIC & \multirow{2}{*}{$\Delta$ AIC } \\
\hline- & 1962.9 & 5 & 3935.8 & 254.35 \\
Water level + Site & 1838.94 & 8 & 3693.88 & 12.43 \\
Water level $\times$ Site & $\mathbf{1 8 3 0 . 7 3}$ & $\mathbf{1 0}$ & $\mathbf{3 6 8 1 . 4 5}$ & $\mathbf{0}$ \\
Water level + Site + Water level $^{2}$ & 1834.24 & 9 & 3686.47 & 5.02 \\
Water level $\times$ Site + Water level & \\
Water level + Site + Time & 1830.06 & 11 & 3682.12 & 0.67 \\
Water level + Site + SPL & 1838.84 & 9 & 3695.69 & 14.24 \\
Water level + Site + Duration & 1838.74 & 9 & 3695.48 & 14.03 \\
Water level + Site + Time + SPL & 1838.72 & 9 & 3695.44 & 13.98 \\
Water level + Site + Time + Duration & 1838.69 & 10 & 3697.37 & 15.92 \\
Water level $\times$ Site + Time & 1838.66 & 10 & 3697.33 & 15.88 \\
Water level $\times$ Site + SPL & 1830.62 & 11 & 3683.23 & 1.78 \\
Water level $\times$ Site + Duration & 1830.62 & 11 & 3683.23 & 1.78 \\
Water level $\times$ Site + Time + SPL & 1830.54 & 12 & 3683.23 & 1.78 \\
Water level $\times$ Site + Time + Duration & 1830.54 & 12 & 3685.07 & 3.62 \\
& & & & 3.63 \\
\hline
\end{tabular}

\section{RESULTS}

\section{Beluga detections and anthropogenic noise events}

In the subset of data analyzed for anthropogenic noise across the 7 selected mooring sites (see 'Anthropogenic noise and water level data'), the duration of beluga detection and anthropogenic noise data ranged from 2.6 to $81.3 \mathrm{~d}$ (Table 1). Beluga whales were detected at all mooring sites, but the proportion of $1 \mathrm{~h}$ sampling occasions for which belugas were detected by either EARs or C-PODs was $<5 \%$ for most sites (Table 1). Only 3 mooring locations (Eagle River, Trading Bay, and Tuxedni Bay) recorded beluga whales on $>5 \%$ of EAR sampling occasions, and only 1 location (Eagle River) recorded beluga whales on $>5 \%$ of C-POD sampling occasions. 
The number of noise events at mooring sites ranged from $\sim 150 \mathrm{~d}^{-1}$ at Cairn Point to $<1 \mathrm{~d}^{-1}$ at Tuxedni Bay (Table 1). There were relatively few anthropogenic noise events at Eagle River, Trading Bay, and Tuxedni Bay, the mooring sites with the greatest proportion of beluga detections.

Castellote et al. (2016a) identified a total of 13 sources of anthropogenic noise: commercial ship, dredging, helicopter, jet aircraft (commercial or military non-fighter), jet aircraft (military fighter), outboard engine (small skiffs, rafts), pile driving, propeller aircraft, sub-bottom profiler, unclassified machinery (continuous mechanical sound, e.g. engine), unidentified 'clank or bang' (impulsive mechanical sound, e.g. barge dumping), unidentified (unclassifiable anthropogenic sound), and unknown up- or down-sweep (modulated tone of mechanical origin, e.g. hydraulics). Eagle River is north of Anchorage, in one of the arms of Cook Inlet, and away from the acoustic footprint of the main shipping traffic in and out of the Port of Anchorage; outboard engine noise from small vessels was the only shipping-related noise detected here. However, this location is in the vicinity of a joint US Airforce and Army military base, and thus aircraft noise was very prevalent. Trading Bay is located in the lower west side of the upper Inlet, 66 miles $(\sim 106 \mathrm{~km})$ southwest of Anchorage. The area is exposed to commercial shipping traffic heading to or from the Port of Anchorage, as well as to drilling rig tenders and offshore supply vessels diverging to and from Tyonek, which assist the multiple hydrocarbon platforms operating in this region of Cook Inlet. Therefore, commercial ship noise and unclassed machinery, probably connected with hydrocarbon related vessel operations, dominate the soundscape in this location. Tuxedni Bay is located in the midwest area of the lower Inlet, and although this mooring location is further away from the shipping lanes heading to the Port of Anchorage, tanker and barge traffic heading to or from the Drift River oil terminal is dense in this area (Eley 2012). Therefore, this site is predominantly exposed to hydrocarbon production shipping noise. Table 4 summarizes the proportion of anthropogenic noise events detected by class, month, and location for the data analyzed; for more details see Castellote et al. (2016a).

There was not an obvious difference in the relationship between time since the last anthropogenic noise event ended and $1 \mathrm{~h}$ sampling occasions in which beluga whales were and were not detected at Eagle River, Trading Bay, and Tuxedni Bay (Fig. 2). Beluga whales were generally detected during lower
Table 4. Proportion of anthropogenic noise classes by location, month, and year detected in the EAR data from the 3 mooring sites in Cook Inlet, Alaska, USA, suitable to evaluate potential spatial displacement by anthropogenic noise

\begin{tabular}{|c|c|c|}
\hline $\begin{array}{l}\text { Location } \\
\text { Month and year }\end{array}$ & Noise class & $\begin{array}{l}\text { No. of } \\
\text { events }\end{array}$ \\
\hline \multicolumn{3}{|l|}{ Eagle River } \\
\hline August & Jet aircraft non-fighter & 1 \\
\hline \multirow[t]{5}{*}{2010} & Jet aircraft military fighter & 30 \\
\hline & Outboard engine & 21 \\
\hline & Propeller aircraft & 2 \\
\hline & Unidentified & 1 \\
\hline & Monthly total & 55 \\
\hline \multirow{4}{*}{$\begin{array}{l}\text { September } \\
2010\end{array}$} & Jet aircraft military fighter & 38 \\
\hline & Outboard engine & 7 \\
\hline & Unidentified & 4 \\
\hline & Monthly total & 49 \\
\hline \multicolumn{3}{|l|}{ Trading Bay } \\
\hline February & Commercial ship & 94 \\
\hline \multirow[t]{2}{*}{2012} & Unclassed machinery & 23 \\
\hline & Monthly total & 117 \\
\hline March & Commercial ship & 88 \\
\hline \multirow[t]{3}{*}{2012} & Unclassed machinery & 115 \\
\hline & Unidentified clank or bang & 1 \\
\hline & Monthly total & 204 \\
\hline April & Commercial ship & 62 \\
\hline \multirow[t]{3}{*}{2012} & Unclassed machinery & 144 \\
\hline & Unidentified & 2 \\
\hline & Monthly total & 208 \\
\hline \multicolumn{3}{|l|}{ Tuxedni Bay } \\
\hline March & Commercial ship & 22 \\
\hline \multirow[t]{5}{*}{2012} & Propeller aircraft & 1 \\
\hline & Unclassed machinery & 1 \\
\hline & Unidentified & 3 \\
\hline & Unidentified clank or bang & 1 \\
\hline & Monthly total & 28 \\
\hline
\end{tabular}

water levels at these mooring locations (Fig. 3); this relationship was particularly noticeable at Eagle River. Fig. 4 shows the bivariate distribution of $1 \mathrm{~h}$ sampling occasions in which beluga whales were detected relative to both water level and time since the last anthropogenic noise event ended, as well as the distribution of all $1 \mathrm{~h}$ sampling occasions relative to these 2 variables.

\section{Occupancy models}

We used EAR detection data to model beluga occupancy at all 3 sites. Beluga detections by C-PODs were limited at Tuxedni Bay and Trading Bay; therefore, we only used detection data from C-PODs to model beluga occupancy at Eagle River. 


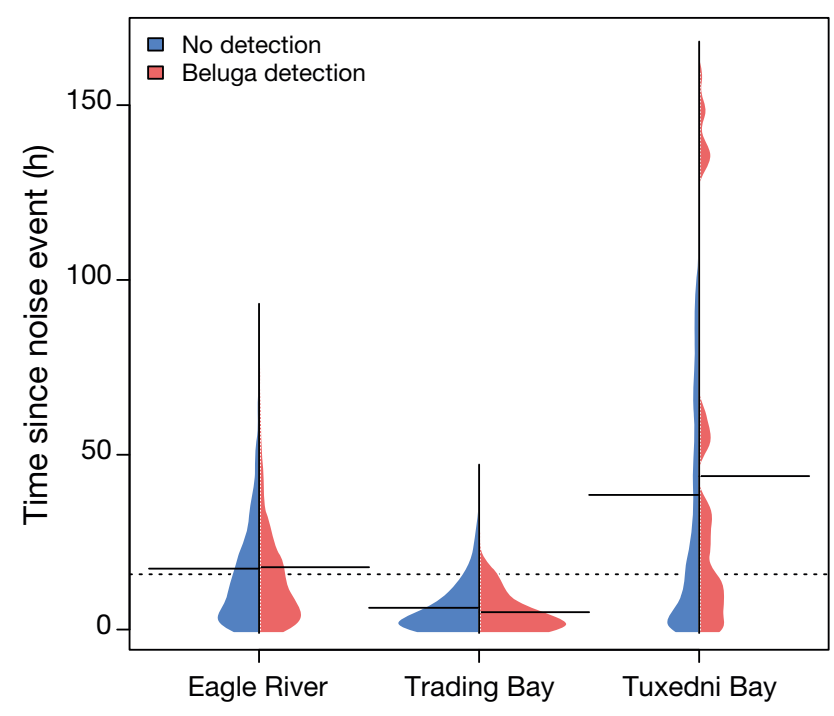

Fig. 2. Distributions of $1 \mathrm{~h}$ sampling occasions relative to time since last anthropogenic noise events ended at Eagle River, Trading Bay, and Tuxedni Bay. Distributions of sampling occasions in which no beluga whales were detected shown in blue; distributions of sampling occasions in which beluga whales were detected by either device (i.e. EAR or C-POD) shown in red. Solid black lines: average time since noise event ended for each group (i.e. combination of site and detection/non-detection distribution); dashed line: average over all $1 \mathrm{~h}$ sampling occasions at the 3 mooring sites

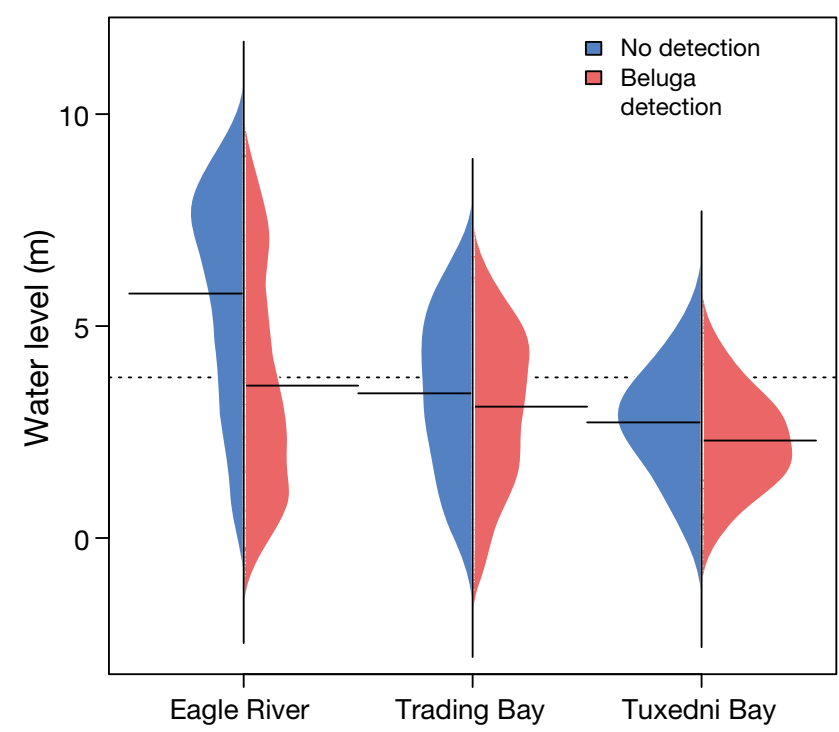

Fig. 3. Distributions of $1 \mathrm{~h}$ sampling occasions relative to water level at Eagle River, Trading Bay, and Tuxedni Bay. Distributions of sampling occasions in which no beluga whales were detected shown in blue; distributions of sampling occasions in which beluga whales were detected by either device (i.e. EAR or C-POD) shown in red. Solid black lines: average water depth for each group (i.e. combination of site and detection/non-detection distribution); dashed line: average over all $1 \mathrm{~h}$ sampling occasions at the 3 mooring sites
Among our set of candidate models for the thinning process, the model with the best predictive ability consisted of site and device effects only (Table 2). The best predicting model for the trend process consisted of the interaction between water level and site (Table 3); other candidate models lacked empirical support $(\triangle \mathrm{AIC}>5$ for the next best model, excluding models with uninformative parameters). As determined by the goodness-of-fit test, all candidate trend and thinning process models fit the data adequately ( $p>0.70)$, except the intercept-only trend model (Table 3, top row; $\mathrm{p}<0.01$ ). Parameter estimates and standard errors for all candidate models are provided in the Supplement at www.int-res.com/articles/suppl/ n032p043_supp.pdf.

The contrast between the best predicting models (of those considered) and the rest indicates important features for both the thinning and trend processes. For the trend process, the interaction of water level and site is clearly more important than additive effects of water level and site. This interaction implies that the effect of water level is heterogeneous across sites. Thus, at some sites, water level had a much more pronounced effect on trends in beluga detections than at others. For the thinning process, models including both site and device (additively) were important. The need for both effects in this component of the model suggests that thinning of beluga whale detections varies substantially across sites and device types.

\section{DISCUSSION}

To our knowledge, this is the first study where the potential for spatial displacement of marine mammals by anthropogenic noise was analyzed through occupancy modeling. Thus, future monitoring efforts could improve the predictive ability of occupancy models if detections are consistently obtained from both devices deployed at each of the sites in the study.

The results of our formal model comparison using AIC revealed that, while the top predicting models relied on significant environmental predictors (e.g. tide and site), the noise-related predictors (e.g. SPL, time since noise event, etc.) did not aid the predictive ability and also did not result in significant effects in the model (see the Supplement). Thus, we can safely conclude that there was not strong evidence for any effects on either the trend or thinning process due to noise-related predictors. Therefore, regardless of closure, we cannot conclude that noise-related predictors influence occupancy status or detectability based on the available data. 


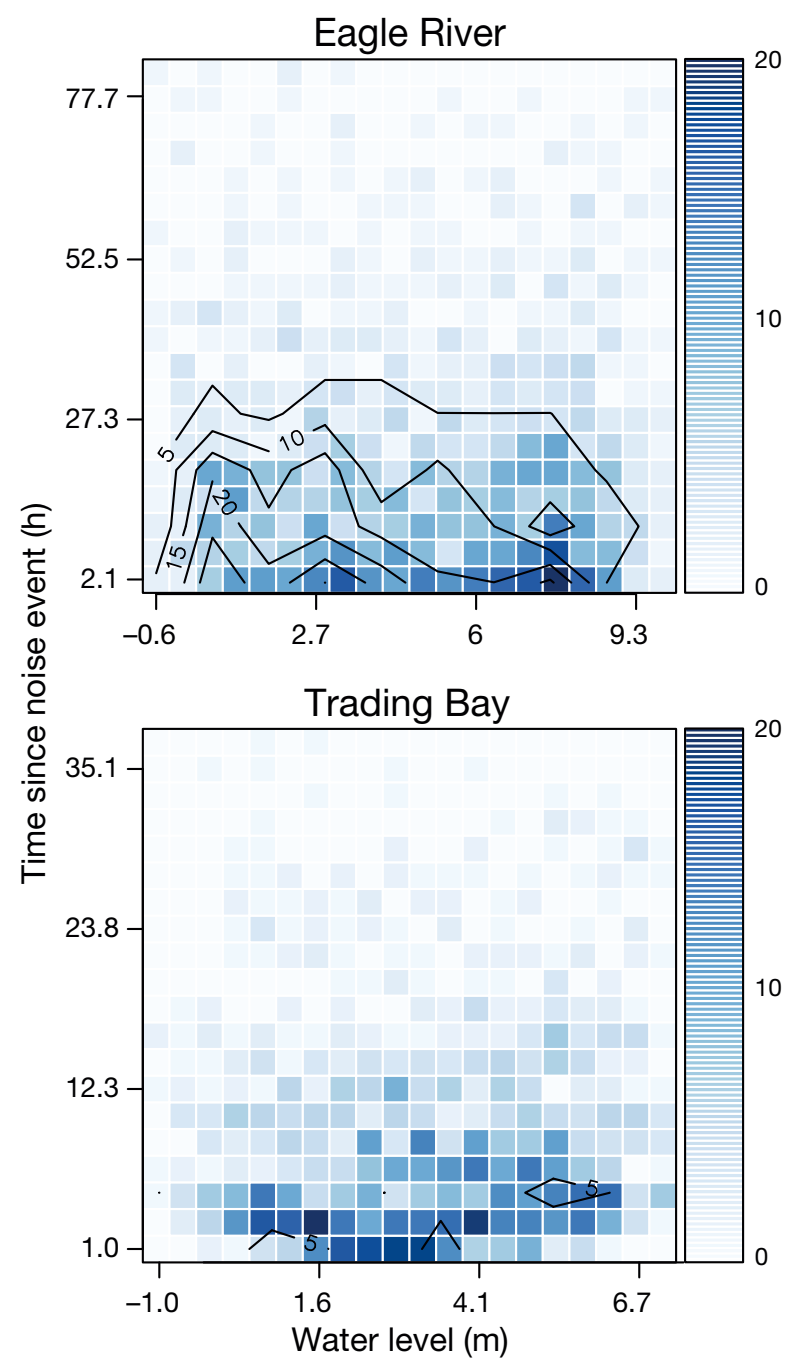

The site level effects for the thinning process were expected because each site contains specific and varying environmental conditions that make beluga whales more difficult to detect (Table 2). However, 2 noise metrics appeared in high-ranking models as covariates for the thinning process: SPL and noise duration appeared in high-ranking models that also included site and device-related covariates, but did not out-perform the simpler models. We would expect noise to be physically related to detectability because very loud noises would mask beluga vocalizations. However, according to Arnold (2010), we may not have enough evidence to say that these additional noise metrics lead to better predicting models. The average sound pressure level of noise events in the selected mooring sites ranged from 98 to $107 \mathrm{~dB}_{\text {rms }}$ re $1 \mu \mathrm{Pa}$, indicating that the majority of noise events in these locations were not very loud. The spectral energy content of these anthropogenic

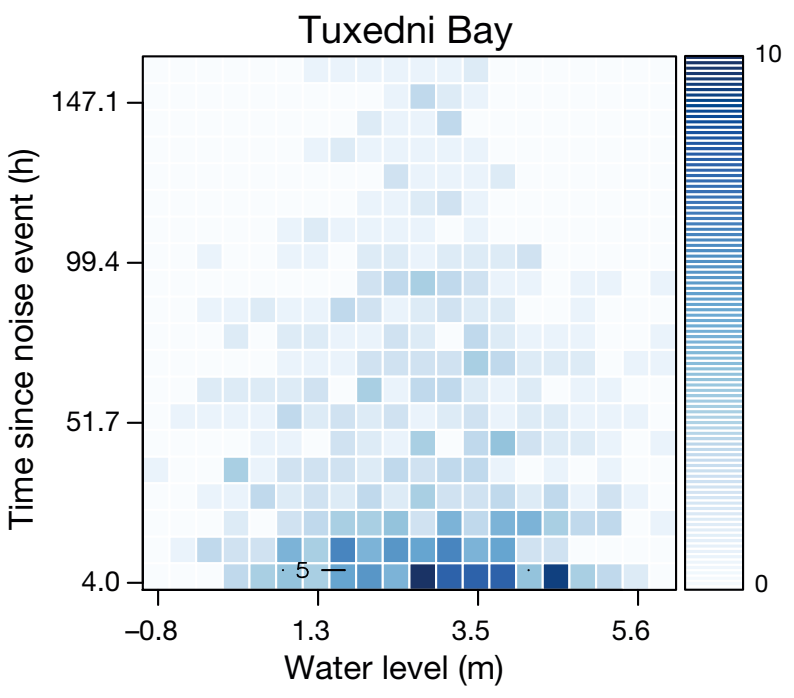

Fig. 4. Bivariate distributions of $1 \mathrm{~h}$ sampling occasions relative to times since noise event and water level at Eagle River, Trading Bay, and Tuxedni Bay. Blue heatmap is a 2-dimensional histogram representing the distribution of all $1 \mathrm{~h}$ sampling occasions (consisting of occasions in which beluga whales were and were not detected); color gradient corresponds to the number of $1 \mathrm{~h}$ sampling occasions in each bin. Distribution of sampling occasions in which beluga whales were detected by either device (i.e. EAR or C-POD) shown as contours. Contours are labeled according to the number of $1 \mathrm{~h}$ sampling occasions and occur in increments of 5

noise events is concentrated in the lower frequencies, only partially overlapping the typically used communication channel by belugas and normally below their echolocation channel (Castellote et al. 2016a). Therefore, the detectability of acoustic beluga signals might not be compromised by the presence of these noise levels. While this might explain, in part, why models including SPL and noise duration did not outperform simpler models, it does not imply that beluga communication, hearing, and behavior might not be affected by the exposure to these moderate noise levels. Anthropogenic noise signals outside the communication and echolocation channel, or partially overlapping but well below masking levels, have been reported to generate significant behavioral responses in other odontocetes (e.g. Tyack et al. 2011, Dyndo et al. 2015).

After we account for the thinning process, the covariate water level appears to have the most predic- 
tive power for trends in beluga detections (Table 3). In the larger set of models, noise-related covariates (i.e. duration, SPL, time since last noise event ended) never appeared in the highest-ranking model but did appear in the slightly less competitive models. This result indicates that after considering site and water level, certain noise metrics may be helpful in predicting beluga detections, but substantial evidence for that was lacking in our particular dataset.

Among the models containing the covariates water level and site, both clearly affect the trend process to some extent; however, the unique interaction of the 2 covariates appears to provide the best predictive model (Table 3). This interaction result implies that the effect of water level on trends in beluga detections varies by site. Furthermore, after accounting for the thinning process, the data suggest that beluga detections increase with lower water levels (Fig. 5) at the sites we analyzed. However, certain sites (i.e. Eagle River) show a stronger relationship between water level and detection trends than others (i.e. Trading Bay and Tuxedni Bay). These results are in accordance with the general knowledge of beluga habitat use in Cook Inlet, where tide level is a major driver of beluga presence in shallow areas (i.e. mud flats, inlet arms) (Moore et al. 2000, Goetz et al. 2007, 2012, Ezer et al. 2008). Belugas use the flooding tide to temporarily access shallow waters, predominantly in Eagle Bay and further up in Knik Arm; thus, we see the stronger relationship between water level and detection trends in the Eagle River dataset. In reality, we might expect a quadratic effect of water

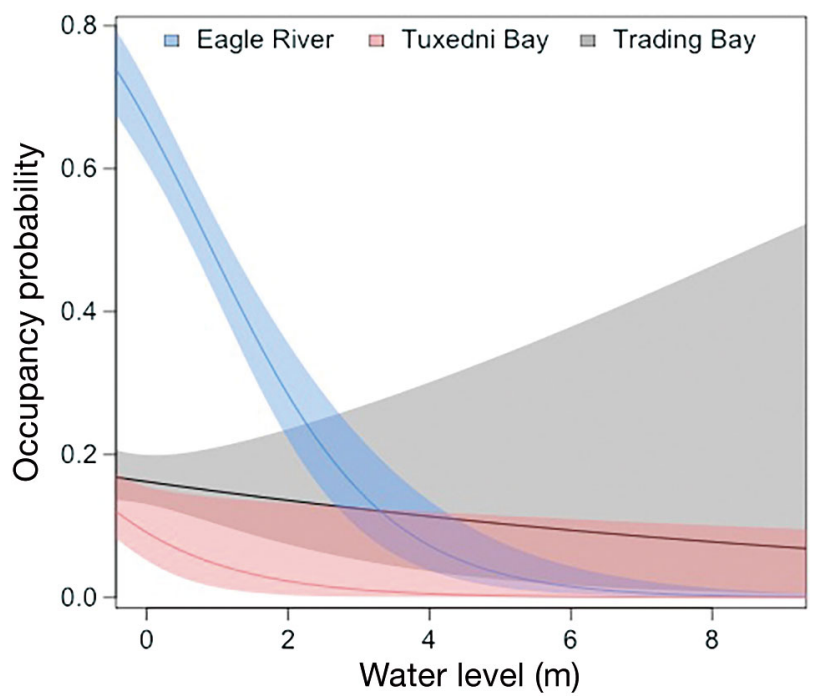

Fig. 5. Relationship between beluga occupancy and water level at Eagle River, Trading Bay, and Tuxedni Bay. Mean estimates are shown with heavy lines; corresponding 95\% confidence intervals represented by shaded regions level on beluga whales such that detections decrease toward zero with increasingly low water levels. Eagle River is too shallow to provide access to belugas at low tide, and thus belugas prefer this area during the initial phase of the flooding cycle or the final phase of the ebbing cycle. The highest tide level period is probably used to access the upper area of Knik Arm, or on some occasions, upstream areas of Eagle River (M. Castellote unpubl. data). However, the available C-POD and EAR datasets do not appear to represent enough very low water levels to substantially support a quadratic water level effect (Table 3). This could be related to the acoustic detection range at Eagle River. Belugas tend to mill in the southern area of Eagle Bay during the low tide period, waiting for the flooding cycle that allows them to move farther inside Knik Arm, into shallower areas. If belugas are within detection range while milling at low tide south of Eagle Bay, a quadratic water level effect will not be supported by the distribution of detections across the tidal cycle.

The modeling results provide a formal confirmation of the relatively weak patterns of differentiation between occasions with and without beluga detections (Figs. 2 \& 3). Fig. 2 indicates similar patterns in detections and non-detections with respect to time since the last anthropogenic noise events ended among all sites. The only possible exception occurs at Tuxedni Bay, where the time between noise events may be longer overall than the other sites, thus allowing for an extended tail of detections, i.e. belugas are detected more often when time between noise events is longer. Fig. 2 clearly illustrates the overall noise distributions and how they vary among sites, with Trading Bay experiencing the shortest gaps between noise events, Eagle River slightly longer, and Tuxedni Bay the longest. These differences are in agreement with the amount and concentration of anthropogenic noise events detected in each location (Castellote et al. 2016a). Fig. 3 also confirms that the sites are similar in beluga detection vs. non-detection with respect to water level. The possible exception is at Eagle River where there appears to be a shift in the distribution of detections toward lower water levels, as explained above.

We conducted our analysis on data from just 3 mooring locations from a subset $(\sim 11.7 \%)$ of data obtained in the 2008-2013 study that was analyzed for anthropogenic noise (Castellote et al. 2016a). However, even though much more data are available from that study to analyze the effects of anthropogenic noise on Cook Inlet belugas, the relatively low density of detections consistently obtained at all 
mooring locations provides little information concerning beluga whale behavior, thus limiting the ability to conduct rigorous evaluations of the impact of environmental conditions and noise on beluga whale spatial displacement. The lack of an evident spatial displacement effect in beluga presence by anthropogenic noise in the results presented here should not be interpreted as the general condition for Cook Inlet belugas. We did not select the 3 sites (Eagle River, Trading Bay, and Tuxedni Bay) where this effect was analyzed because of the potential for interactions between anthropogenic noise and beluga presence, but rather because these were the sites with the highest beluga detections. Perhaps the higher presence of belugas in these sites could be related to a lower degree of noise disturbance. In fact, these 3 sites present some of the lowest background noise levels of all the locations sampled during the 5 yr study. However, beluga preference for low background noise areas has never been demonstrated. On the other hand, beluga avoidance of loud background noise areas is difficult to demonstrate. The 7 locations selected by Castellote et al. (2016a) had the greatest proportion of beluga detections among all 13 locations but relatively few anthropogenic noise events. In particular, Eagle River and Tuxedni Bay had the highest percent of beluga presence and lowest anthropogenic noise events (Table 1). This apparent inverse relationship could be coincidental or caused by the specific period selected for the analysis, or it could reflect a preference for quieter zones within the beluga's distribution range. The relationship between quieter areas and beluga presence within their critical habitat should be explored further to assess how to potentially incorporate noise into Cook Inlet spatial planning. Specifically, identifying sites to protect their natural acoustic environment could facilitate conservation gains while minimizing industrial costs (see Williams et al. 2015).

Beluga acoustic behavior is complex and most likely plays an important role in the capacity to detect spatial displacement caused by anthropogenic noise using remote acoustic monitoring methods. There is evidence of a decrease in or even a ceasing of the acoustic activity of belugas in the presence of natural predators (i.e. killer whales) or engine noise disturbance (Morgan 1979, Lesage et al. 1999, Karlsen et al. 2002, Van Parijs et al. 2003, Castellote \& Fossa 2006); these changes in beluga behavior have been associated with threat, startle, fright, alarm, or stress contexts and interpreted as a survival strategy to avoid detection by predators (Schevill 1964, Fish \& Vania 1971, Morgan 1979, Lesage et al. 1999). Therefore, a lower density of beluga detections in areas with higher anthropogenic noise could be related to beluga signals being masked by noise, a change in acoustic behavior, and spatial displacement, or a combination of all these effects. However, Cook Inlet belugas are forced to echolocate to navigate through murky waters, and thus, incorporating echolocation signals (i.e. C-POD data) into the acoustic detection results could compensate for this behavioral reaction. A study of beluga presence in Knik Arm identified a reduction of social signals, but not echolocation signals, during pile-driving activities near the Port of Anchorage (Kendall et al. 2013). Furthermore, the frequency range of such anthropogenic noise typically overlaps with the frequency range of beluga social signals, but rarely do such anthropogenic noises reach the higher frequency range used for echolocation. Thus, detection probability is more robust against masking or behavioral changes induced by anthropogenic noise when both social signals and echolocation of belugas are available.

Another important factor to consider is the beluga detection temporal resolution used in our analysis. Because a repeated-measures design is necessary to run occupancy models and because the beluga detection data was processed in $1 \mathrm{~h}$ resolution, the inference concerning the trend process was relative to $3 \mathrm{~h}$ subperiods. This period is relatively homogenous with respect to dynamic environmental conditions, yet shorter sampling periods may be required to detect potential spatial displacement in Cook Inlet. Unfortunately, the very limited knowledge on beluga behavioral response to noise disturbance impedes any assessment of the influence of sampling periods on detection of spatial displacement.

Our study demonstrates the applicability of occupancy modeling to assess potential negative effects on marine mammals by anthropogenic noise, and we recommend such modeling be considered in future marine mammal displacement studies. The limitations in the data we analyzed could be addressed in data collection protocols of future acoustic studies designed to determine if Cook Inlet belugas respond to anthropogenic noise by exhibiting spatial displacement. Specifically, because the primary objective of the study in Cook Inlet was acoustic detection of beluga whales over several years, the amount of beluga detections in our data was insufficient for several reasons (e.g. EAR data obtained on a $10 \%$ dutycycle, low number of beluga detections when processed in $1 \mathrm{~h}$ resolution, $3 \mathrm{~h}$ sampling periods, etc.), which, when combined, restricted modeling possibilities. Furthermore, future monitoring efforts will be 
particularly useful if they incorporate multiple detection devices per site that are duty-cycled such that detections are temporally aligned. Our study used 2 different types of detection devices, but these did not always operate in unison, reducing our ability to rely on replication to separate detection from occurrence. Nevertheless, our temporal occupancy modeling approach for the acoustic data provided a better phenomenological model to predict beluga detections than a logistic regression (based on a preliminary analysis not included here), but without closure, we cannot interpret the results strictly in terms of detection and occupancy processes (instead only as background trend and thinning).

Statistical models for traditional observer-based surveys that are commonly used in other areas of wildlife ecology may still be applicable in aquatic settings when passive detection devices are employed. We paired occupancy models with detections of beluga whales that were treated as binary response variables, but so-called $N$-mixture models (Royle 2004) could serve as an alternative approach if the number of detections per time period were modeled instead. Like occupancy models, $N$-mixture models require replication in the survey design to separate occurrence from detectability. When sites or time periods are near each other such that dependence in detections occurs beyond that accounted for by the available covariates, the model assumptions may not be met and the resulting inference may be questionable. More sophisticated approaches such as spatially explicit occupancy models (Johnson et al. 2013a) are useful for accommodating latent sources of dependence among sites or time periods. Finally, other statistical methods may also be useful for acoustic detection data. For example, point process models (Johnson et al. 2013b) have been used extensively in resource selection studies involving telemetry data and have even been used to model the timing of volcanic eruptions and historic wildfire events. Point process models may better accommodate the various characteristics of the acoustic detection data, but the theoretical underpinnings of point process models present technical challenges that currently limit their immediate utility.

In summary, the results of our study are inconclusive. Anthropogenic noise metrics (e.g. SPL and noise duration) appeared in high-ranking models as covariates for the trend process, but the data were insufficient to indicate better predictive ability beyond those models that only included environmental covariates. Future studies that implement protocols designed specifically for beluga occupancy will be most effective for accurately estimating the effect of noise on beluga displacement. The recent assessment of noise sources in Cook Inlet (Castellote et al. 2016a) indicates that anthropogenic noise occurring in some of the most important habitat for this endangered species (i.e. Area 1 critical habitat) has the potential to mask beluga communication and hearing and that the potential reduction of communication and echolocation range is considerable. Thus, consistent with the primary recovery action for the potential threat of noise (NMFS 2016), research studies designed specifically to address beluga displacement need to be conducted in areas of known importance (e.g. Susitna Delta and lower Knik Arm) and during key periods (e.g. summer feeding) to evaluate the potential for spatial displacement.

Acknowledgements. This study would have not been possible without all the collective effort from the team of researchers that conducted the Cook Inlet beluga acoustic study: Justin Jenniges, Alaska Department of Fish Game; Marc Lammers, Hawaii Institute of Marine Biology; and Shannon Atkinson, University of Alaska Fairbanks. Del Westerholt provided critical support in the design of acoustic moorings and deployment logistics in upper Cook Inlet. Christopher Garner, Joint Base Elmendorf Richardson, provided critical logistic support during field work in Knik Arm. Special thanks are due to Dave McKay and Bill Choate, the 2 vessel operators whose efforts were instrumental in the deployment and recovery of acoustic moorings in Cook Inlet during the study. Comments from 2 anonymous reviewers improved a previous version of this manuscript. This publication was partially funded by the Joint Institute for the Study of Atmosphere and Ocean (JISAO) under NOAA Cooperative Agreement NA15OAR4320063 (2015-2020). Any use of trade, firm, or product names is for descriptive purposes only and does not imply endorsement by the U.S. government.

\section{LITERATURE CITED}

Arnold TW (2010) Uninformative parameters and model selection using Akaike's information criterion. J Wildl Manag 74:1175-1178

Au WWL, Carder DA, Penner RH, Scronce BL (1985) Demonstration of adaptation in beluga whale echolocation signals. J Acoust Soc Am 77:726-730

Au WWL, Penner RH, Turl CW (1987) Propagation of beluga echolocation signals. J Acoust Soc Am 82:807-813

Burnham KP, Anderson DR (2002) Model selection and multimodel inference: a practical information-theoretic approach. Springer-Verlag, New York, NY

Castellote M, Fossa F (2006) Measuring acoustic activity as a method to evaluate welfare in captive beluga whales (Delphinapterus leucas). Aquat Mamm 32:325-333

Castellote M, Clark CW, Lammers MO (2012) Acoustic and behavioural changes by fin whales (Balaenoptera physalus) in response to shipping and airgun noise. Biol Conserv 147:115-122 
Castellote M, Thayre B, Mahoney M, Mondragon J, Schmale C, Small RJ (2016a) Anthropogenic noise in Cook Inlet beluga habitat: sources, acoustic characteristics, and frequency of occurrence. Final Wildlife Research Report ADF\&G/DWC/WRR-2016-4. Alaska Department of Fish and Game, Juneau, AK

Castellote M, Small RJ, Lammers MO, Jenniges JJ, Mondragon J, Atkinson S (2016b) Dual instrument passive acoustic monitoring of beluga whales in Cook Inlet, Alaska. J Acoust Soc Am 139:2697-2707

Chmelnitsky EG, Ferguson SH (2012) Beluga whale, Delphinapterus leucas, vocalizations from the Churchill River, Manitoba, Canada. J Acoust Soc Am 131:4821-4835

Clark CW, Ellison WT, Southall BL, Hatch L, Van Parijs SM, Frankel A, Ponirakis D (2009) Acoustic masking in marine ecosystems: intuitions, analysis, and implication. Mar Ecol Prog Ser 395:201-222

* Cosens SE, Dueck LP (1993) Icebreaker noise in Lancaster Sound, N.W.T., Canada: implications for marine mammal behavior. Mar Mamm Sci 9:285-300

Cox TM, Ragen TJ, Read AJ, Vos E and others (2006) Understanding the impacts of anthropogenic sound on beaked whales. J Cetacean Res Manag 7:177-187

Dekeling RPA, Tasker ML, Ainslie MA, Andersson M and others (2014) Monitoring guidance for underwater noise in European seas. JRC Scientific and Policy Report EUR 26557 EN. Publications Office of the European Union, Luxembourg 2014

* Dyndo M, Wiśniewska DM, Rojano-Doñate L, Madsen PT (2015) Harbour porpoises react to low levels of high frequency vessel noise. Sci Rep 5:11083

Eley WD (2012) Cook Inlet vessel traffic study. Report to Cook Inlet Risk Assessment Advisory Panel. Cape International, Juneau, AK

Erbe C (2000) Detection of whale calls in noise: performance comparison between a beluga whale, human listeners, and a neural network. J Acoust Soc Am 108:297-303

Erbe C, King AR, Yedlin M, Farmer DM (1999) Computer models for masked hearing experiments with beluga whales (Delphinapterus leucas). J Acoust Soc Am 105: 2967-2978

Ezer T, Hobbs R, Oey LY (2008) On the movement of beluga whales in Cook Inlet, Alaska: simulations of tidal and environmental impacts using a hydrodynamic inundation model. Oceanography 21:186-195

Finley KJ, Miller GW, Davis RA, Greene CR (1990) Reactions of belugas, Delphinapterus leucas, and narwhals, Monodon monoceros, to ice-breaking ships in the Canadian High Arctic. In: Smith TG, St. Aubin DJ, Geraci JR (eds) Advances in research on the beluga whale. Canadian Bulletin of Fisheries and Aquatic Sciences 224. Department of Fisheries and Oceans, Canada, Ottawa, p 97-117

Finneran JJ, Schlundt CE, Carder DA, Clark JA, Young JA, Gaspin JB, Ridgway SH (2000) Auditory and behavioural responses of bottlenose dolphin (Tursiops truncatus) and white whale (Delphinapterus leucas) to impulsive sounds resembling distant underwater signatures of underwater explosions. J Acoust Soc Am 108:417-431

Finneran JJ, Schlundt CE, Dear R, Carder DA, Ridgway SH (2002) Temporary shift in masked hearing thresholds in odontocetes after exposure to single underwater impulses from a seismic water gun. J Acoust Soc Am 111:2929-2940

Fish JF, Vania JS (1971) Killer whale, Orcinus orca, sounds repel white whales, Delphinapterus leucas. Fish Bull 69: 531-535
Fiske I, Chandler R (2011) Unmarked: an R Package for fitting hierarchical models of wildlife occurrence and abundance. J Stat Softw 43:1-23

Fleishman E, Streever B, Angliss R, Clark CW and others (2016) Current status of development of methods to assess effects of cumulative or aggregated underwater sounds on marine mammals. In: Popper AN, Fay RR (eds) The effects of noise on aquatic life II. Springer, New York, NY, p 303-311

Ford JKB (1989) Acoustic behavior of resident killer whales (Orcinus orca) off Vancouver Island, British Columbia, Canada. Can J Zool 67:727-745

Goetz KT, Rugh DJ, Read AJ, Hobbs RC (2007) Habitat use in a marine ecosystem: beluga whales Delphinapterus leucas in Cook Inlet, Alaska. Mar Ecol Prog Ser 330:247-256

Goetz KT, Montgomery RA, Ver Hoef JM, Hobbs RC, Johnson DS (2012) Identifying essential habitat of the endangered beluga whale Delphinapterus leucas in Cook Inlet, Alaska. Endang Species Res 16:135-147

Harwood LA, Smith TG, Joynt A, Kennedy D, Pitt R, Moore S, Millman P (2010) Displacement of whales and seals by seismic and exploratory drilling in the Canadian Beaufort Sea. Conference presentation. Canada-United States Northern Oil and Gas Research Forum, Nov 30-Dec 2, 2010, Calgary, Alberta, Canada

Harwood J, King S, Booth C, Donovan C, Schick RS, Thomas L, New L (2016) Understanding the population consequences of acoustic disturbance for marine mammals. In: Popper AN, Fay RR (eds) The effects of noise on aquatic life II. Springer, New York, NY, p 417-423

*Heide-Jørgensen MP, Hansen RG, Westdal K, Reever RR, Mosbech A (2013) Narwhals and seismic exploration: Is seismic noise increasing the risk of ice entrapments? Biol Conserv 158:50-54

Hobbs RC, Shelden KEW, Rugh DJ, Norman SA (2008) 2008 status review and extinction risk assessment of Cook Inlet belugas (Delphinapterus leucas). AFSC Processed Report 2008-02. Alaska Fisheries Science Center, National Maine Fisheries Service, NOAA, Seattle, WA

Kohnson DS, Conn PB, Hooten MB, Ray J, Pond B (2013a) Spatial occupancy models for large data sets. Ecology 94 : 801-808

*Johnson DS, Hooten MB, Kuhn CE (2013b) Estimating animal resource selection from telemetry data using point process models. J Anim Ecol 82:1155-1164

Karlsen JD, Bisther A, Lydersen C, Haug T, Kovacs KM (2002) Summer vocalizations of adult male white whales (Delphinapterus leucas) in Svalbard, Norway. Polar Biol 25:808-817

Kendall LS, Sirovic A, Roth EH (2013) Effects of construction noise on the Cook Inlet beluga whale Delphinapterus Leucas vocal behavior. Can Acoust 41:3-13

Laidre KL, Shelden KEW, Rugh DJ, Mahoney BA (2000) Beluga, Delphinapterus leucas, distribution and survey effort in the Gulf of Alaska. Mar Fish Rev 62:27-36

Kammers MO, Castellote M, Small RJ, Atkinson S and others (2013) Passive acoustic monitoring of Cook Inlet beluga whales (Delphinapterus leucas). J Acoust Soc Am 134:2497-2504

* Lesage V, Barrette C, Kingsley MCS, Sjare B (1999) The effect of vessel noise on the vocal behavior of Belugas in the St. Lawrence River estuary, Canada. Mar Mamm Sci 15:65-84

MacKenzie DI, Bailey LL (2004) Assessing the fit of siteoccupancy models. J Agric Biol Environ Stat 9:300-318 
MacKenzie DI, Nichols JD, Lachman GB, Droege S, Royle JA, Langtimm CA (2002) Estimating site occupancy rates when detection probabilities are less than one. Ecology 83:2248-2255

MacKenzie DI, Nichols JD, Royle JA, Pollock KH, Bailey LL, Hines JE (2006) Occupancy estimation and modeling. Elsevier, Burlington, MA

Miller GW, Moulton VD, Davis RA, Holst M, Millman P, MacGillvray A, Hannay D (2005) Monitoring seismic effects on marine mammals - southeastern Beaufort Sea, 2001-2002. In: Armsworthy SL, Cranford PJ, Lee K (eds) Offshore oil and gas environmental effects monitoring: approaches and technologies. Battelle Press, Columbus, OH, p 511-542

Moore SE, Shelden KEW, Litzky LK, Mahoney BA, Rugh DJ (2000) Beluga whale, Delphinapterus leucas, habitat associations in Cook Inlet, Alaska. Mar Fish Rev 62: $60-80$

Morgan DW (1979) The vocal and behavioural reactions of the beluga whale, Delphinapterus leucas, to playback of its sounds. In: Winn HE, Olla BL (eds) Behaviour of marine animals: current perspectives in research, Vol. 3. Cetaceans. Plenum Press, New York, NY, p 311-343

New LF, Moretti DJ, Hooker SK, Costa DP, Simmons SE (2013) Using energetic models to investigate the survival and reproduction of beaked whales (family Ziphiidae). PLOS ONE 8:e68725

NMFS (National Marine Fisheries Service) (2016) Recovery Plan for the Cook Inlet beluga whale (Delphinapterus leucas). National Marine Fisheries Service, Alaska Region, Protected Resources Division, Juneau, AK

Noren DP, Dunkin RC, Williams TM, Holt MM (2012) Energetic cost of behaviors performed in response to vessel disturbance: one link in the population consequences of acoustic disturbance model. In: Popper AN, Fay RR (eds) The effects of noise on aquatic life II. Springer, New York, NY, p 427-430

Nowacek DP, Thorne LH, Johnston DW, Tyack PL (2007) Responses of cetaceans to anthropogenic noise. Mammal Rev 37:81-115

NRC (National Research Council) (2005) Marine mammal populations and ocean noise: determining when noise causes biologically significant effects. National Academy Press, Washington, DC

O'Corry-Crowe G, Suydam RS, Rosenber A, Frost KJ, Dizon AE (1997) Phylogeography, population structure and dispersal patterns of the beluga whale Delphinapterus leucas in the western Neartic revealed by mitochondrial DNA. Mol Ecol 6:955-970

R Core Team (2014) R: a language and environment for statistical computing. R Foundation for Statistical Computing, Vienna. www.R-project.org

Richardson WJ, Würsig B (1997) Influences of man-made noise and other human actions on cetacean behavior. Mar Freshw Behav Physiol 29:183-209

Editorial responsibility: Brandon L. Southall (Guest Editor), Santa Cruz, California, USA
Richardson WJ, Greene CR, Malme CI, Thomson DH (1995) Marine mammals and noise. Academic Press, San Diego, CA

Royle JA (2004) N mixture models for estimating population size from spatially replicated counts. Biometrics 60: 108-115

Rugh DJ, Shelden KEW, Mahoney BA (2000) Distribution of beluga whales, Delphinapterus leucas, in Cook Inlet, Alaska, during June/July 1993-2000. Mar Fish Rev 62: $6-21$

Scheifele PM, Andrew S, Cooper RA, Darre M, Musiek FE, Max L (2005) Indication of a Lombard vocal response in the St. Lawrence River beluga. J Acoust Soc Am 117: 1486-1492

Schevill WE (1964) Underwater sounds of cetaceans. In: Tavolga WN (ed) Marine bio-acoustics. Pergamon Press, London, p 307-316

Schlundt CE, Finneran JJ, Carder DA, Ridgway SH (2000) Temporary shift in masked hearing thresholds of bottlenose dolphins, Tursiops truncatus, and white whales, Delphinapterus leucas, after exposure to intense tones. J Acoust Soc Am 107:3496-3508

Shelden KEW, Sims CL, Vate Brattström L, Goetz KT, Hobbs RC (2015) Aerial surveys of beluga whales (Delphinapterus leucas) in Cook Inlet, Alaska, June 2014. AFSC Processed Rep. 2015-03. Alaska Fisheries Science Center, NOAA, Natl Mar Fish Serv, Seattle, WA. www.afsc. noaa.gov/Publications/ProcRpt/PR2015-03.pdf

Sjare BL, Smith TG (1986) The vocal repertoire of white whales, Delphinapterus leucas, summering in Cunningham Inlet, Northwest Territories. Can J Zool 64: 407-415

Southall BL, Bowles AE, Ellison WT, Finneran JJ and others (2007) Marine mammal noise exposure criteria: initial scientific recommendations. Aquat Mamm 33:411-521

* Thomsen F, Franck D, Ford JKB (2001) Characteristics of whistles from the acoustic repertoire of resident killer whales (Orcinus orca) off Vancouver Island, British Columbia. J Acoust Soc Am 109:1240-1246

Tyack PL, Clark CW (2000) Communication and acoustic behavior of dolphins and whales. Popper AN, Au WWL, Fay RR (eds) Hearing by whales and dolphins. Springer, New York, NY, p156-224

Tyack PL, Zimmer WMX, Moretti D, Southall BL and others (2011) Beaked whales respond to simulated and actual naval sonar. PLOS ONE 6:e17009

*Van Parijs SM, Lydersen C, Kovacs KM (2003) Sounds produced by individual white whales, Delphinapterus leucas, from Svalbard during capture (L). J Acoust Soc Am 113:57-60

Williams R, Erbe C, Ashe E, Clark CW (2015) Quiet(er) marine protected areas. Mar Pollut Bull 100:154-161

Wright AJ, Kyhn LA (2015) Practical management of cumulative anthropogenic impacts with working marine examples. Conserv Biol 29:333-340

Submitted: November 17, 2015; Accepted: November 3, 2016 Proofs received from author(s): January 5, 2017 